\title{
FOOD-RELATED COPING STRATEGIES ADOPTED BY SOME HOUSEHOLDS DURING COVID-19 LOCKDOWN IN NIGERIA
}

\author{
${ }^{1}$ Ariyo, O., ${ }^{1}$ Samuel, F. O., ${ }^{* 1}$ Eyinla, T. E., ${ }^{1}$ Leshi, O. O, ${ }^{2}$ Brai, B. I. C. \& ${ }^{3}$ Afolabi, W.O. \\ ${ }^{I}$ Department of Human Nutrition and Dietetics, University of Ibadan, Ibadan, Nigeria \\ ${ }^{2}$ Department of Biochemistry, Federal University, Oye-Ekiti, Ekiti, Nigeria. \\ ${ }^{3}$ Department of Nutrition and Dietetics, Federal University of Agriculture, Abeokuta, Nigeria
}

*Corresponding Author Email: toluemma@ymail.com Phone: +2348068467771

\begin{abstract}
As part of the measures to contain the spread of the COVID-19 virus in Nigeria during the early stages of the pandemic, a lockdown of movements within and from outside the country was declared by the federal government. This article presents findings on food-related coping strategies adopted during the COVID-19 lockdown in Nigeria. A cross sectional survey using an online based questionnaire received responses from 883 households regarding information on food consumption, health seeking behaviour and food coping strategies during the COVID-19 lockdown. Food Coping Strategy Index (FCSI) was computed from the data received based on standard methods. Analysis and presentation of data was done using descriptive and inferential statistics. The key findings show that daily mealtimes generally reduced from an average of 3 to 2 times. The storage capacity of households showed an average of 2 -week food stock of staples, and most of the respondents had started reducing either their usual portion sizes or frequency of meals in order to cope with food shortages. As regards health seeking behavior, older respondents were more likely to take prophylactic medication $(\mathrm{p}<0.004)$ and there was a higher preference for fruits and Vitamin C as prophylactic items. A negative correlation between FCSI with mealtime during COVID-19 lockdown ( $<<0.000)$ and monthly income $(\mathrm{p}<0.000)$ was observed. The findings presented provide information for policy intervention in the areas of social safety nets and palliatives disbursement in the event of similar lockdown restrictions in the future.
\end{abstract}

Keywords: COVID-19, Food coping strategies, Food consumption, Food security, Lockdown, Nigeria

LICENSE: This work by Open Journals Nigeria is licensed and published under the Creative Commons Attribution License 4.0 International License, which permits unrestricted use, distribution, and reproduction in any medium, provided this article is duly cited.

COPYRIGHT: The Author(s) completely retain the copyright of this published article.

OPEN ACCESS: The Author(s) approves that this article remains permanently online in the open access (OA) model.

QA: This Article is published in line with "COPE (Committee on Publication Ethics) and PIE (Publication Integrity \& Ethics)". 


\section{INTRODUCTION}

SARS-COV-2 now popularly referred to as COVID-19 is a severe acute respiratory viral infection which belongs to the large category of eight human respiratory infections and a sub-family of 7 coronaviruses (WHO, 2021). This novel virus came into limelight when it was first reported in China in December 2019 (Li et al., 2020) and beyond this first instance, there was an unprecedented spread globally which caused the WHO to declare its spread as a pandemic in March 2020 (Sohrabi, 2020). The index case of COVID-19 in Nigeria was confirmed in Lagos on February 27, 2020 after which the virus began to spread across the country. In order to curb the spread, the federal government decided on March 23, 2020 to close its borders and restricted flights movements both within and from outside the country. This closure was also followed with full or partial lockdown in some states.

Since the breakout of the global pandemic, all the pathways of the world's food system had been affected by the pandemic including food supply and food consumption (WFP 2020; World Bank 2020). In developed countries, the robust social protection structures (e.g food banks) helped in cushioning the reduced access to food which was caused by COVID-19 pandemic and its associated lockdowns. However, in many countries (including Nigeria), the lockdown aggravated the experience of food insecurity mainly because of poor and limited coverage of social protection programmes (Amare et al., 2020; Samuel et al., 2021; Andam et al., 2021).

Reports across African countries reflect a preponderance of income shocks, rising food insecurity and worsen dietary quality in Nigeria, Kenya, Uganda and Ghana (Amare et al., 2020; Kansiime et al., 2020; Asiedu et al., 2020; Egger et al., 2021). These reports confirm the projection that people and households globally facing acute food insecurity could increase from 135 million to 270 million due to income and remittance losses, and disruption of food system associated with pandemic (WFP, 2020). Nigeria's nationwide COVID-19 lockdown restrictions imposed in first quarter of 2020 was predicted to also affect an already fragile food system. For a while, food insecurity has been an intractable problem in Nigeria characterized by high hunger index, low food consumption score and high calorie deficiency (Global Hunger Index 2019), high food price fluctuation (Amare et al., 2020), and food cost accounting for $56-75 \%$ of household expenditures (FAO, 2020).

The role of dietary intake and nutrition in promoting immunity and health which is critical in reducing vulnerability of being infected with coronaviruses and improving chances of survival in case of infection, is well known (WHO, 2021). The pandemic disrupted economies and food systems globally and locally, with extensive food security ramifications (Niles et al, 2020), however food- related coping strategies during the lockdown is one that has not been widely explored, as it is a completely new and recent experience globally. Questions still persist unanswered; was there a change in food consumption practices due to lockdowns? Were any coping strategies applied due to the lockdowns? What factors drove the strategies of individuals and households during these peculiar times? To this end, this study sought to answer specific research questions of how COVID-19 associated lockdown has affected firstly, mealtimes of Nigerians, secondly, their food related health-seeking behavior, and lastly the coping strategies deployed to circumvent the associated increased burden of household food insecurity. 


\section{METHODOLOGY STUDY DESIGN}

This cross-sectional survey was conducted between April and May 2020 during the peak of COVID-19 lockdowns in Nigeria. Sampling was done using snowballing technique (referral method of sampling respondents) which resulted in a total of 883 respondents as at when the survey closed. The snowballing approach was achieved through the initial sharing of the electronic questionnaire via messaging platforms like WhatsApp firstly with members of the nutrition network across Nigeria and then a specific request upon completion was that the questionnaire be further shared with the respondent's contacts and groups within and outside the state of residence. A question on current state of residence was asked so as to obtain the location of the respondent.

\section{DATA COLLECTION}

A semi-structured questionnaire was designed, scripted and administered through an online survey form (Google forms). The questionnaire comprised of 3 sections, a) demographic and socioeconomic characteristics of the respondents, b) food consumption of the respondents before and during COVID-19 lockdown, c) food coping strategies of the respondents during COVID-19 lockdown. Before being administered, a validation test was carried out among staff of the authors' institutions. Adjustments were included as advised after the validation test.

\section{DATA ANALYSIS}

Responses from the online questionnaire were transferred from a spreadsheet into statistical software (SPSS Version 20) where data management was carried out. Socio-demographic and food consumption data were presented in frequency counts and percentages. Questions relating to Food Coping Strategies Index (FCSI) were recoded and classified based on methodology presented by Maxwell and Caldwell (2008). The study's cleaned data was analyzed and presented using descriptive and inferential statistics. Correlation and Chi-square tests were used to test for statistical associations between selected variables. Significance was set at $\mathrm{p}<0.05$ and $\mathrm{p}<0.001$.

\section{ETHICAL APPROVAL}

All respondents gave written informed consent before participation

\section{RESULTS AND DISCUSSION CHARACTERISTICS OF RESPONDENTS}

The majority of the responders (62\%) were female and lived in metropolitan regions $(60.3 \%)$. The respondents were young and middle-aged persons aged 21-30 years (37.1\%) and 31-40 years (30.4\%), respectively, according to the age categories. More than half of the households (55.3\%) had $4-6$ members, while a total of $19 \%$ had members in excess of seven. One-third (36.3\%) of the respondents did not generate any income in the past one month before the survey indicating the possible effect of the lockdown on trade, business and income generation activities. 
Table 1: Socio-demographic characteristics of respondents

\begin{tabular}{|c|c|c|c|}
\hline & Male $(\%)$ & Female $(\%)$ & Total $(\%)$ \\
\hline \multicolumn{4}{|c|}{ Categorization of neighborhood $(n=865)$} \\
\hline Rural & $27(3.1)$ & $45(5.2)$ & $72(8.3)$ \\
\hline Semi-Urban & $99(11.4)$ & $158(18.3)$ & $257(29.7)$ \\
\hline Urban & $218(25.2)$ & $318(36.8)$ & $536(62.0)$ \\
\hline \multicolumn{4}{|l|}{ Age Category (n=863) } \\
\hline$<20$ years & $5(0.6)$ & $3(0.3)$ & $8(0.9)$ \\
\hline 21-30 years & $96(11.1)$ & $224(26.0)$ & $320(37.1)$ \\
\hline $31-40$ years & $135(15.6)$ & $127(14.7)$ & $262(30.4)$ \\
\hline $41-50$ years & $59(6.8)$ & $98(11.4)$ & $157(18.2)$ \\
\hline $51-60$ years & $39(4.5)$ & $51(5.9)$ & $90(10.4)$ \\
\hline $61-70$ years & $6(0.7)$ & $16(1.9)$ & $22(2.5)$ \\
\hline \multicolumn{4}{|l|}{ Household Size (n=852) } \\
\hline$<3$ members & $101(11.9)$ & $121(14.2)$ & $222(26.1)$ \\
\hline $4-6$ members & $165(19.4)$ & $306(35.9)$ & $471(55.3)$ \\
\hline$>7$ members & $67(7.9)$ & $92(10.8)$ & $159(18.6)$ \\
\hline \multicolumn{4}{|c|}{ Usual monthly income in Naira $(\mathbf{n}=829)$} \\
\hline$<10000$ naira & $31(3.7)$ & $77(9.3)$ & $108(13.0)$ \\
\hline $10,000-49,999$ naira & $72(8.7)$ & $130(15.7)$ & $202(24.4)$ \\
\hline 50,000-99,999 naira & $54(6.5)$ & $90(10.9)$ & $144(17.4)$ \\
\hline 100,000-149,999 naira & $71(8.6)$ & $81(9.8)$ & $152(18.3)$ \\
\hline$>150,000$ naira & $105(12.7)$ & $118(14.2)$ & $223(26.9)$ \\
\hline \multicolumn{4}{|c|}{ Source of generated income in the last 30 days $(n=864)$} \\
\hline Did not generate income & $111(12.8)$ & $203(23.5)$ & $314(36.3)$ \\
\hline Main Occupation & $159(18.4)$ & $236(27.3)$ & $395(45.7)$ \\
\hline Secondary Occupation & $53(6.1)$ & $53(6.1)$ & $106(12.3)$ \\
\hline \multicolumn{4}{|l|}{ Secondary occupation $(n=865)$} \\
\hline No & $220(25.4)$ & $346(40.0)$ & $566(65.4)$ \\
\hline Yes & $125(14.5)$ & $174(20.1)$ & $299(34.6)$ \\
\hline Main and Secondary Occupation & $20(2.3)$ & $29(3.4)$ & $49(5.7)$ \\
\hline
\end{tabular}

Figure 1 describes the average mealtime frequency before and during the lockdown. Before the restrictions caused by the pandemic, most respondents claimed to eat at least 3 times in a day (58.9\%). This reduced as at the time of the survey (during pandemic lockdown) to 2 times daily (47.1\%). This reduction in frequency of mealtimes was also observed in UK households (Defeyter et al., 2020) and its implication is obvious for adequate dietary intake and by extension diet quality. Despite the exemption of Nigeria's agri-food systems from lockdown restrictions, the obvious impact of reduced economic or physical access is seen by the comparatively reduced meal frequency reported by the respondents. A scenario simulation of Nigeria's food security situation pre- and post-lockdown confirms this occurrence and the future possibility of slow recovery (Andam et al., 2021). The Federal Government of Nigeria with support from some charitable organizations provided palliative measures in form of food distribution to cushion the 
effects of the food insecurity across the states of the federation. However, the poor logistics of distribution and operational plan led to crisis in some states as citizens broke into warehouses where the palliative foods were kept and carted away the foods.

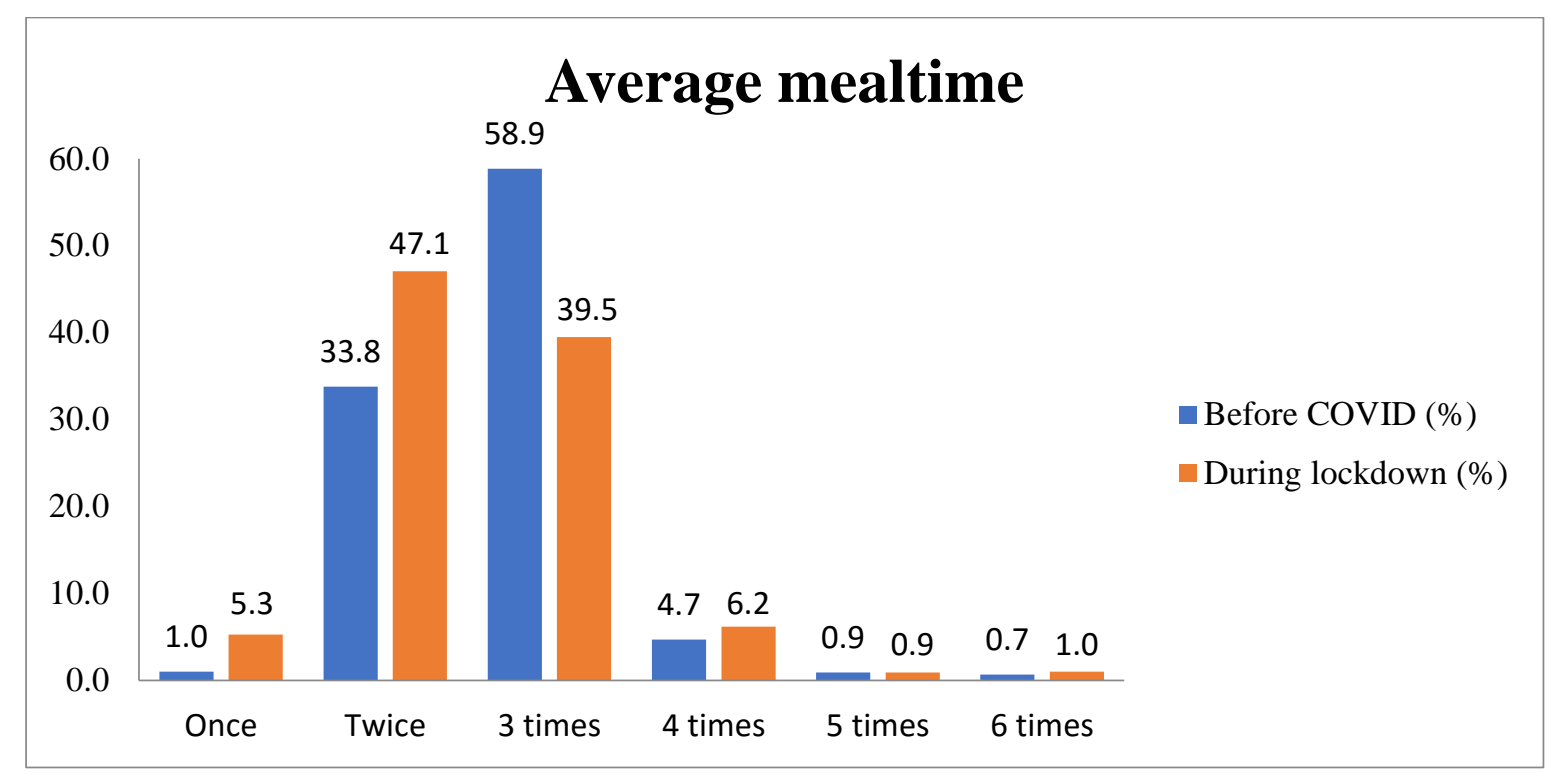

Figure 1: Average mealtime before and during COVID lockdown

\section{HEALTH SEEKING BEHAVIOR DURING LOCKDOWN}

As shown in Table 2. Fruits (35.9\%) ranked the most mentioned food item consumed purposively for protection against being infected. It was followed by vegetables (22.7\%), and spices (16.2\%). This underscores the belief of the respondents in the health benefits of fruits, vegetables and spices. Of all 274 respondents who took prophylactic medications, Vitamin C was consumed by $19.4 \%$ while antimalarial drugs were taken by only 12 (1.4\%). Over twothird $(70 \%)$ were worried of becoming infected when in a food market. 
Table 2: Health Seeking Behavior during lockdown

\begin{tabular}{lcl}
\hline & Frequency & \% of Total \\
\hline Food specially consumed as protection against COVID-19 $(\mathbf{n = 6 9 1 )}$ & \\
Fruits & 317 & 35.9 \\
Vegetables & 200 & 22.7 \\
Spices & 143 & 16.2 \\
Herbal mixtures & 31 & 3.5
\end{tabular}

Are there medications that you had consumed/are consuming to provide protection against COVID-19 $(n=274)$

Vitamin C $\quad 171 \quad 19.4$

Multivitamins and supplements $\quad 62 \quad 7.0$

$\begin{array}{lll}\text { Spice and herbs } & 29 & 3.3\end{array}$

Antimalarial drugs $\quad 12 \quad 1.4$

Do you worry you might become infected when you go to market to get food? $(\mathrm{n}=870)$

$\begin{array}{lll}\text { Yes } & 609 & 70.0\end{array}$

No $261 \quad 30.0$

Table 3 shows that households with 4-6 members consistently bought more foods (26.4\%) and medications (15.9\%) compared to other household size categories, however, both behaviors were not significant $(\mathrm{p}=0.730$ and $\mathrm{p}=0.900)$. Specifically, older respondents were taking medications in comparison to younger respondents $(p=0.004)$. The highest category of those purchasing medicines were those earning above 200,000 naira (US\$400) $(\mathrm{p}<0.001)$. Generally, there were more respondents in the older categories who engaged in behavior of purchasing prophylactic food $/ \mathrm{medications}$. Expectedly, the older respondents may have underlying illnesses and therefore be more health conscious but for the younger respondents, this may be a reflection that the they either did not have the ability to purchase or did not know what to buy. The latter suggestion is supported by a study that assessed knowledge of adolescents on health seeking behaviors (Ogubuike, 2021).

Table 3: Prophylactic behavior during lockdown with socio-demographic

\begin{tabular}{|c|c|c|c|c|c|c|c|c|}
\hline & \multicolumn{4}{|c|}{$\begin{array}{l}\text { Are there foods you had consumed/ are consuming to provide } \\
\text { protection against COVID-19? }\end{array}$} & \multicolumn{4}{|c|}{$\begin{array}{l}\text { Are there medications that you had consumed/are consuming to provide } \\
\text { protection against COVID-19? }\end{array}$} \\
\hline & No & Yes & Total & p-value & No & Yes & Total & p -value \\
\hline \multicolumn{9}{|c|}{ Age of respondent } \\
\hline$<20$ years & $5(0.6)$ & $3(0.3)$ & $8(0.9)$ & 0.674 & $6(0.7)$ & $2(0.2)$ & $8(0.9)$ & 0.004 \\
\hline $21-30$ years & $178(20.6)$ & $142(16.4)$ & $320(37.0)$ & & $255(29.7)$ & $62(7.2)$ & $317(36.9)$ & \\
\hline $31-40$ years & $136(15.7)$ & $127(14.7)$ & $263(30.4)$ & & $192(22.3)$ & $71(8.3)$ & $263(30.6)$ & \\
\hline $41-50$ years & $80(9.2)$ & $78(9.0)$ & $158(18.3)$ & & $105(12.2)$ & $52(6.0)$ & $157(18.3)$ & \\
\hline $51-60$ years & $45(5.2)$ & $45(5.2)$ & $90(10.4)$ & & $59(6.9)$ & $30(3.5)$ & $89(10.3)$ & \\
\hline$>60$ years & $11(1.3)$ & $15(1.7)$ & $26(3.0)$ & & $15(1.7)$ & $11(1.3)$ & $26(3.0)$ & \\
\hline \multicolumn{9}{|c|}{ Monthly Income (naira) } \\
\hline$<10000$ & $72(8.6)$ & $36(4.3)$ & $108(12.9)$ & 0.033 & 93 (11.2) & $14(1.7)$ & 107 (12.9) & 0.000 \\
\hline $10,000-49,999$ & $114(13.6)$ & $93(11.1)$ & $207(24.7)$ & & $156(18.8)$ & $48(5.8)$ & $204(24.5)$ & \\
\hline $50,000-99,999$ & $76(9.1)$ & $69(8.2)$ & $145(17.3)$ & & $103(12.4)$ & $42(5.1)$ & $145(17.4)$ & \\
\hline $\begin{array}{l}100,000- \\
149,999\end{array}$ & $79(9.4)$ & $73(8.7)$ & $152(18.2)$ & & $119(14.3)$ & $32(3.9)$ & $151(18.2)$ & \\
\hline $\begin{array}{l}150,000- \\
199,999\end{array}$ & $35(4.2)$ & $39(4.7)$ & $74(8.8)$ & & $49(5.9)$ & $24(2.9)$ & $73(8.8)$ & \\
\hline$>200,000$ & $70(8.4)$ & $81(9.7)$ & $151(18.0)$ & & $93(11.2)$ & $58(7.0)$ & $151(18.2)$ & \\
\hline
\end{tabular}




\section{FOOD STORAGE CAPACITY}

Most of respondents had stores of staple foodstuff that can last one-two weeks (39.1\%) as shown in Figure 2. Only $0.8 \%$ of the respondents had no foodstuff while about $32 \%$ had food that could only last 1-3 weeks. These results reflect little resilience among the respondents in view of the limited opportunity for income generation due to restricted movement. Although, these results ordinarily may suggest a higher resilience than envisaged in Nigeria where about half of the nation's population is considered food insecure, it is however important to note that the respondents in the current study largely belong to the middle class of the population who may not be considered to be poor. Even though most households reported a substantial quantity of food stock in readiness to avoid hunger, the worry of running out of supplies if the restrictions persisted is previously reported (Samuel et al., 2021; Ogunji et al., 2021).

\section{How long can current store of food stuff last (\%)}

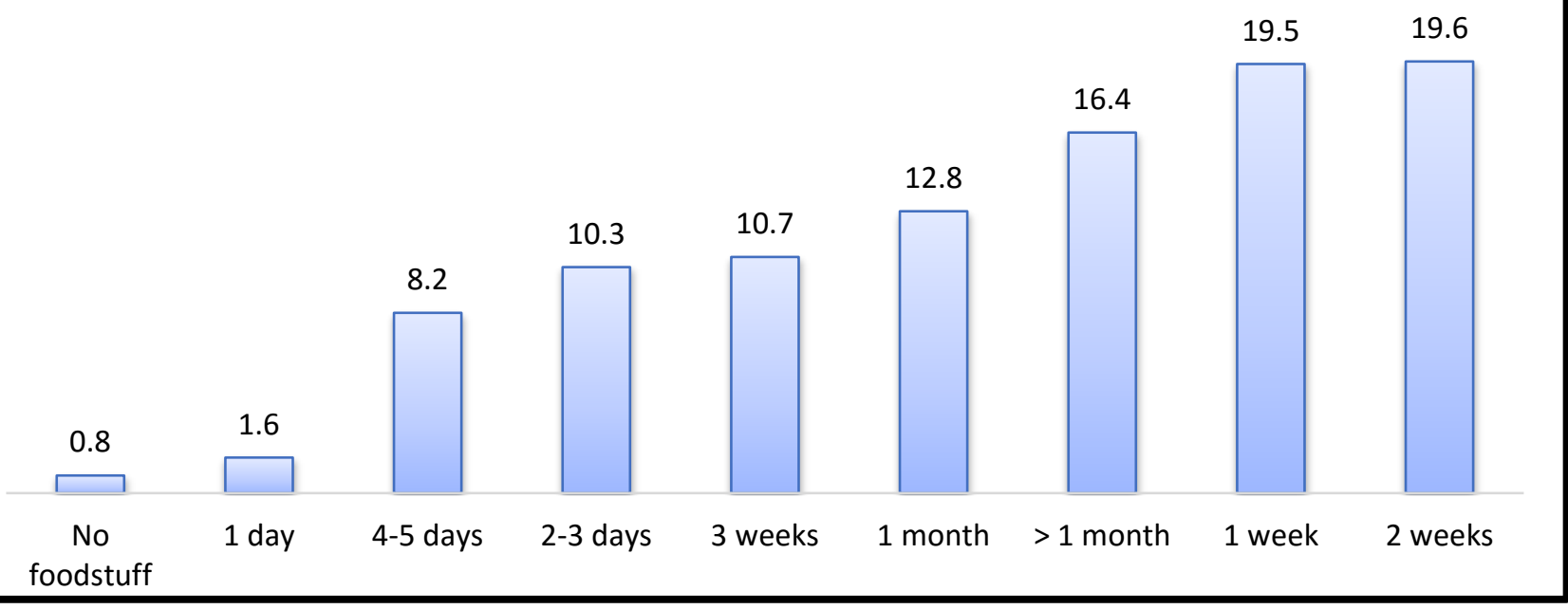

Figure 2: Current household store of foodstuff

\section{FOOD COPING STRATEGIES}

The predominant daily coping strategies adopted were the reduction of the portion of meals (23.8\%), frequency of meals (20.4\%), and reliance on cheaper food (13.8\%). Overall, all respondents were deploying some form of food rationing (Table 4a and 4b). An evaluation of food coping strategies in Ethiopian (Tsegaye et al., 2018) and Nigerian (Iheme et al., 2020) households presented similar results showing a reduction in food portion size as the most reported response in coping with food insecurity. A further worrisome coping strategy identified in Nigerian households was the sale of assets (Koos et al., 2020). However, in a study of American households, the most reported coping strategy was buying foods that would not go bad quickly (Niles et al 2020). A correlation of variables (Table 5) shows a significant negative correlation between FCSI with mealtime during COVID-19 lockdown $\left(r^{2}=-0.342, p<0.01\right)$ and monthly income $\left(\mathrm{r}^{2}=0.287, \mathrm{p}<0.01\right)$. A positive correlation was observed between monthly income and mealtime during the lockdowns $\left(r^{2}=-0.102, p<0.01\right)$. These relationships align with other studies that observed the impact of lockdown on eating frequency and economic access to food (Abdul, 2020; Iheme et al., 2020). In some other settings, 
the socioeconomic status also featured as a prominent factor influencing ability to cope adequately with lockdowns

(Das et al., 2020)

Table 4a: Food Coping Strategies adopted during lockdown period

\begin{tabular}{|c|c|c|c|c|c|}
\hline Not at all $(\%)$ & $\begin{array}{l}\text { 1-2 days } \\
(\%)\end{array}$ & $\begin{array}{l}\text { 3-4 days } \\
(\%)\end{array}$ & 4-5days (\%) & $\begin{array}{l}\text { Everyday } \\
(\%)\end{array}$ & $\begin{array}{l}\text { Total } \\
(\%)\end{array}$ \\
\hline \multicolumn{6}{|c|}{ Relied on less preferred, less expensive food } \\
\hline $424(49.2)$ & $193(22.4)$ & $107(12.4)$ & $19(2.2)$ & $119(13.8)$ & $862(100.0)$ \\
\hline \multicolumn{6}{|c|}{ Borrowed food or relied on help from friends or relatives } \\
\hline $731(84.9)$ & $69(8.0)$ & $28(3.3)$ & $19(2.2)$ & $14(1.6)$ & $861(100.0)$ \\
\hline \multicolumn{6}{|c|}{ Reduced the number of meals eaten per day } \\
\hline $474(55.3)$ & $151(17.6)$ & $44(5.1)$ & $13(1.5)$ & $175(20.4)$ & $857(100.0)$ \\
\hline \multicolumn{6}{|l|}{ Reduced portion size of meals } \\
\hline $480(55.8)$ & $112(13.0)$ & $45(5.2)$ & $18(2.1)$ & $205(23.8)$ & $860(100.0)$ \\
\hline \multicolumn{6}{|c|}{ Reduction in the quantities consumed by adults/mothers } \\
\hline $609(70.9)$ & $78(9.1)$ & $33(3.8)$ & $9(1.0)$ & $130(15.1)$ & $859(100.0)$ \\
\hline
\end{tabular}

Table 4b: Food Coping Strategies Index (FCSI) categories

\begin{tabular}{lll}
\hline & Frequency & $\%$ \\
\hline No/Low Coping & 0 & 0 \\
Medium Coping & 357 & $42.8 \%$ \\
High Coping & 478 & $57.2 \%$ \\
\hline
\end{tabular}

Table 5: Correlation of CSI with study variables

\begin{tabular}{|c|c|c|c|c|}
\hline & FCSI & $\begin{array}{l}\text { Age of } \\
\text { respondent }\end{array}$ & $\begin{array}{ll}\text { Mealtime } & \text { before } \\
\text { COVID-19 } & \end{array}$ & $\begin{array}{ll}\text { Mealtime } & \text { during } \\
\text { COVID-19 } & \end{array}$ \\
\hline Age of respondent & -0.034 & 1 & & \\
\hline Mealtime before COVID-19 & $0.222^{* *}$ & $-0.074^{*}$ & 1 & \\
\hline Mealtime during COVID-19 & $-0.342^{* *}$ & -0.015 & $0.120^{* *}$ & 1 \\
\hline Monthly income & $-0.287^{* *}$ & $0.521^{* *}$ & $-0.151^{* *}$ & $0.102^{* *}$ \\
\hline
\end{tabular}




\section{CONCLUSION}

This study evaluated food consumption practices, food coping strategies and health-seeking behaviour of Nigerians during the lockdown of movements and activities in the year 2020 due to the COVID-19 virus pandemic. Generally, the findings indicate that there was some worriness about food insecurity if the lockdown extended further. Specifically, the findings show that daily mealtimes generally reduced from an average of three to two meals per day. As regards, health seeking behavior, older respondents were more likely to consume prophylactic food or medication and there was a higher preference for fruits, vegetables and Vitamin $\mathrm{C}$ during this lockdown period. Most of the respondents had started reducing either their usual portion sizes or frequency of meals and few had started relying on cheaper options. The findings presented provide information for policy intervention in the areas of social safety nets and palliatives disbursement in the event of similar lockdown restrictions in the future or during period of emergencies. We hereby posit that if any event such as a lockdown were to re-occur, a food systems approach of preventing food insecurity from production down to consumption will be best suited to prevent harmful coping strategies.

\section{ACKNOWLEDGEMENT}

The authors appreciate all respondents who filled the questionnaire and assisted in sharing with their contacts. Elizabeth Okonkwo is also appreciated for editorial assistance.

\section{CONFLICT OF INTEREST}

None 


\section{REFERENCES}

Abdul, I.M. (2020). Covid-19, Lockdown and Transitory Food Insecurity in Nigeria. Food and Agribusiness Management. 1(1), 26-30.

Amare, M., Abay, K.A., Tiberti, L. \& Chamberlin, J., 2020. Impacts of COVID-19 on food security: Panel data evidence from Nigeria (Vol. 1956). International Food Policy Research Institute. https://doi.org/10.2499/p15738coll2.133866.

Andam, K., Edeh, H., Oboh, V., Pauw, K., \& Thurlow, J. (2020). Impacts of COVID-19 on food systems and poverty in Nigeria. Advances in Food Security and Sustainability. 5: 145-173. https://doi.org/10.1016/bs.af2s.2020.09.002.

Asiedu, E., Sadekla, S.S. and Bokpin, G.A., 2020. Aid to Africa's agriculture towards building physical capital: Empirical evidence and implications for post-COVID-19 food insecurity. World Development Perspectives. 20,p.100269. https://doi.org/10.1016/j.wdp.2020.100269

Béné, C., 2020. Resilience of local food systems and links to food security-A review of some important concepts in the context of COVID-19 and other shocks. Food Security, pp.1-18. https://doi.org/10.1007/s12571-02001076-1

Das, S., Rasul, M. G., Hossain, M. S., Khan, A. R., Alam, M. A., Ahmed, T., \& Clemens, J. D. (2020). Acute food insecurity and short-term coping strategies of urban and rural households of Bangladesh during the lockdown period of COVID-19 pandemic of 2020: report of a cross-sectional survey. BMJ Open, 10(12), e043365.

Defeyter et al (2020) Food and coping strategies during the COVID-19 pandemic. Retrieved from https://healthylivinguk.org/wp-content/uploads/2020/06/Food-and-coping-strategies-during-the-COVID19-pandemic.pdf_(Accessed August 2020).

Egger, D., et al., (2021). Falling living standards during the COVID-19 crisis: Quantitative evidence from nine developing countries. Science Advances, 7(6), eabe0997.

Food and Agriculture Organization 2020. National Policy Responses to limit the Impact of COVID-19 on Food Markets. Food Policy and Market Developments. Rome, Italy. Food and Agriculture Organization of the United Nations (FAO). http://www.fao.org/giews/food-prices/food-policies/detail/en/c/1270543/. (Accessed August 2020).

Global Hunger Index, (2019). The Challenge of Hunger and Climate Change: The Challenge of Hunegr and Climate Change. International Food Policy Research Institute, Washington, DC, WHH (Welthugerhilfe), Bonn, and Concern worldwide, Dublin.

Iheme, G.O., et al. (2020). Food consumption and coping strategies of urban households in Nigeria. World Nutrition. 11(3): 35-50. https://dx.doi.org/10.2139/ssrn.3703169

Kansiime, M.K., Tambo, J.A., Mugambi, M.I., Bundi, M.M., Kara, A. and Owuor, M.C., (2020). COVID-19 implications on household income and food security in Kenya and Uganda: Findings from a rapid assessment. World Development. p.105199. https://doi.org/10.1016/j.worlddev.2020.105199.

Koos, C., Hangoma, P., \& Mæstad, O. (2020). Household wellbeing and coping strategies in Africa during COVID19-Findings from high frequency phone surveys. CMI Report. Retrieved from 
https://www.cmi.no/publications/7391-household-wellbeing-and-coping-strategies-in-africa-during-covid19-findings-from-high-frequency. (Accessed 24th June).

Li, C., Yang, Y., and Ren, L. (2020). Genetic evolution analysis of 2019 novel coronavirus and coronavirus from other species. Infection, Genetics and Evolution. 82: 1-3.

Maxwell, D. and Caldwell, R., 2008. The Coping Strategies Index: Field Methods Manual Second Edition, January 2008. Retrieved from https://www.fsnnetwork.org/sites/default/files/coping_strategies_tool.pdf. (Accessed on September 2020).

Niles, M. T., Bertmann, F., Belarmino, E. H., Wentworth, T., Biehl, E., \& Neff, R. A. (2020). The Early Food Insecurity Impacts of COVID-19. medRxiv. https://doi.org/10.1101/2020.05.09.20096412.

Ogubuike, C. (2021). Knowledge and Health-seeking Behaviour of Adolescents on COVID-19 in Rivers State, Nigeria. Asian Journal of Research in Nursing and Health, 4(1): 6-16. Retrievedfrom https://www.journalajrnh.com/index.php/AJRNH/article/view/30127.

Ogunji, J., Iheanacho, S., Ogunji, C.V., Olaolu, M., Oleforuh-Okoleh, V., Amaechi, N., David, E., Ndukauba, O., Ikegwu, T.M., Biamba, C., Chinonyerem, D. (2021). Household Hunger and Coping Strategies in SouthEastern Nigeria during Corona Virus Lockdown. Preprints 2021, 2021040793. https://doi.org/10.20944/preprints202104.0793.v1.

Tsegaye, A.T., Tariku, A., Worku, AG, et al. (2018). Reducing amount and frequency of meal as a major coping strategy for food insecurity. Archives of Public Health 76: 56-65. https://doi.org/10.1186/s13690-018-03033.

Samuel, F.O. et al 2021 Food Access and Experience of Food Insecurity in Nigerian Households During the Covid19 Lockdown. Food and Nutrition Sciences, 12, 1062-1072. https://doi.org/10.4236/fns.2021.1211078.

Sohrabi, C., Alsafi, Z., O'neill, N., Khan, M., Kerwan, A., Al-Jabir, A., Iosifidis, C. and Agha, R., (2020). World Health Organization declares global emergency: A review of the 2019 novel coronavirus (COVID-19). International Journal of Surgery, 76: 71-76. https://doi.org/10.1016/j.ijsu.2020.02.034.

World Food Program 2020. COVID-19 will double number of people facing food crises unless swift action is taken. Press Release, April 21, 2020. Retrieved from https://www.wfp.org/news/covid-19-will-double-numberpeople-facing-food-crises-unless-swift-action-taken. (Accessed November 2020).

World Bank 2020. The impact pf COVID-19 (Coronavirus) on global poverty: Why Sub-Saharan Africa might be the region hardest hit. Data Blog. Retrieved from https://blogs.worldbank.org/opendata/impact-COVID-19coronavirus-global-poverty-why-sub-saharan-africa-might-be-region-hardest_(Accessed August 2020).

World Health Organization 2021. Coronavirus disease (COVID-19). https://www.who.int/healthtopics/coronavirus\#tab=tab_1. Accessed December 2021. 